\title{
I Bury the Dead: Poe, Heidegger, and Morbid Literature
}

\author{
DARREN HUTCHINSON
}

When I had waited a long time very patiently without hearing him lie down, I resolved to open a little-a very, very little crevice in the lantern. So I opened ityou cannot imagine how stealthily, stealthily-until at length a single dim ray like the thread of the spider shot out from the crevice and fell upon the vulture eye.

It was open, wide, wide open, and I grew furious as I gazed upon it. I saw it with perfect distinctness - all a dull blue with a hideous veil over it that chilled the very marrow in my bones, but I could see nothing else of the old man's face or person, for I had directed the ray as if by instinct precisely upon the damned spot.

(Edgar Allan Poe, The Tell-Tale Heart)

I.

Heidegger never troubled himself with works of modern fiction. Even though "Dichtung" in German includes fictional works of literature (though such works are also indicated by the terms Fiktion, Bellatristik, and Geschichten), not merely poetry, Heidegger exclusively dedicated his later philosophical admiration of "dichten" to the works of modern poets, finding an uncanny resonance between the work of Hölderlin, Georg, and Trakl and the vibrations of a thinking-yetto-come, an andenkendes Denken. He had nothing whatsoever to say, however, about the work of novelists such as Tieck or Mann. Even though in "The Origin of the Work of Art" he says, "poesy is only one mode of the clearing of true, i.e. of poetic composition," finding all art to be essentially involved in poetic exposure, he continues, "Nevertheless, the linguistic work, poetry 
in the narrower sense, has a privileged position in the domain of arts" (Heidegger 198). In the same paragraph, he links the classical philosophically interesting examples of the arts, architecture, painting, and music to the essence of poetry, but there is no word regarding the novel or short story.

Such neglect is grounded in the essential opening of Heidegger's thought. Although Heidegger was perhaps the fundamental thinker of the thing in the last century, a thinker who first and foremost attempted to rescue things from their decimation through negation, representational annihilation, and technology (all of which were, for Heidegger, aspects of the threat of the withdrawing oblivion of be-ing), there were certain relations to things which were for him too "ontic" to brook philosophical notice, except perhaps to indicate their irrelevance to thinking or even the dangers they pose to the destiny of thinking.

For example, the scene in Poe's story The Tell-Tale Heart from which the above epigram is taken both presents the machinations of a madman's mind, obsessed with the cataracted eye of his elderly landlord, and regales the reader with the plans of a murder plot, as well as descriptions of the surrounding rooms, of feelings, and of the deteriorated eye. However, it seemingly asks no basic questions about the very possibility of the presentation of a scene, the engagement with the other, or the nature of description itself. For the purposes of fundamental ontology and for the thinking-to-come which would follow such ontology—since the work of fiction is never visited after fundamental ontology evolves for Heidegger into other, stranger modes of the saying of be-ing - as for the empirical human sciences, fiction would begin much too late to be significant, already presupposing access to a world of beings (including other human beings), never revealing the opening of this access. 
Similar to the manifold critiques of Heidegger's various "neglects" (of the animal, the body, sex, air - nearly everything) which have arisen over the years, the aim here is largely negative: to expose the limitations of Heidegger's ontological commitments (along with a certain genealogy of those commitments), commitments which lead him to choose one particular genre over another (the "poetic" over the "fictional") and consequently one approach to ontology (and its limits) over another. This aim, however, comes with a caveat. It is only by following the path of Heidegger's thought towards a relation to things beyond metaphysics that the present exposure becomes possible.

Such an exposure would even, perhaps, lead one beyond the pre-ontological projection which discloses all beings and into the togetherness with things in their horrible singularity. The purpose of this essay will be not only to expose Heidegger's turning from and appropriation of certain singular things, but also the investigation of the grounds of this turning appropriation as a wincing recoil from the rot and decay of beings.

II.

Poe's The Tell-Tale Heart speaks of nothing other than another death of things, beyond the deathly relations in which they are encountered in the work of Heidegger. Consider the narrator's account of the motive for the murder he has committed:

It is impossible to say how first the idea entered my brain, but, once conceived, it haunted me day and night. Object there was none. Passion there was none. I loved the old man. He had never wronged me. He had never given me insult. For his gold I had no desire. I think it was his eye! Yes, it was this! One of his eyes resembled that of a vulture-a pale blue eye with a film over it. Whenever it fell upon me my blood ran cold, and so by degrees, very gradually, I made up my mind to take the life of the old man, and thus rid myself of the eye for ever. (295) 
The first thing to be noticed in this passage is what might be called "the fundamental relation to death" of the speaker. Perhaps, in Heidegger's terms, one might be tempted to claim that this character is living in a radically inauthentic fashion, fleeing from the abyss in his own heart. Such a character would deny his own temporal finitude by throwing himself into the project of murder. But such a supposition is nonsense, since the character in fact shows no concern for himself at all, not even the concern of "enjoying himself" in the activity he undertakes. In fact, the character rather opens himself up to the possibility of destruction, and even though the crime is perfectly carried out and there is no evidence, he ends up betraying himself, annihilating his own life through his startling confession.

One might object that, at least for "normal" human beings, the story reveals nothing whatsoever about the fundamental relation to the death of things. The main character, after all, is mad. If I suppose a mad character has anything to teach me then perhaps I would have to be as mad as the character who would be my instructor.

As if I had not had similar experiences throughout life, experiences which all human beings undergo to varying degrees. Such experiences are surely culturally conditioned, they are certainly different in different people, and they are malleable to some degree (such that manipulation in specific cases represents a profound ethical achievement), but one would have to be mad to claim that such experiences are not as "normal" as dreams. It is, after all, quite common to be deeply repelled by the wounded, deformed, or diseased body—or by a cataracted eye.

A personal example: When I was in the Cub Scouts at 8 years of age, there was a scoutmaster who brought about such feelings in me. This woman's husband (about whom I know only this, which is enough) had at some point, in a drunken rage, flung a pot of boiling water in 
her face. This event left her face severely disfigured and she was blind in one eye. I recall going to the meetings and having a difficult time looking at her even though she was one of the most gentle and kind people I ever encountered. At a certain point, I do not know how or when, I learned to "look past" her disfigurement, simply seeing her as "Mrs. B," no longer avoiding her gaze. But I cannot deny that I went through this experience and it was so intense that I remember it to this day.

Despite his madness, Poe's character instantiates this quite normal condition, a condition which I will call a desire for the death of the dead. Such a desire is not a flight from something as ethereal as "the possibility of death," not a horror in the face of the nothingness of oblivion, not a deep anxiety concerning the perpetual erasure of presence as one (and others) become perpetually dead (changed, lost in memory, alien) through the passage inherent to the timeliness of life. Rather, the desire for the death of the dead arises from repulsion in the face of the dead thing, the dying thing, the wounded and rotting, the rend(er)ing of flesh in which it twists beyond the health of the body. In the throes of such repulsion, one turns and wants to flee from the concrete being of oozing sores and scarred skin and mangled faces and limbs. One desires that they simply not exist.

The dead eye of the narrator's victim is, indeed, "vulture-like," not because it is animalistic, not because it reminds the narrator of the bestiality of the human (the character reminds himself of that well enough through his deeds), but rather because it is connected to the decay of carrion, making an almost magical identification between the scavenger-bird and the dead bodies it consumes. This eye, this concrete instance of death in life, obsesses the narrator. The eye, the sign of life, the "window to the soul," the grand metaphor of access to purely intelligible radiance, when it is encountered as a concrete thing, with its white film and burst 
veins and seeping fluid from the corners, has become a thing which he cannot take his eyes off (including the "eye" of his mind).

Such a dead thing is beyond all "conspicuousness" or "obtrusiveness" which would be encountered in dealings with the things of the world of Da-sein. Likewise, this thing is beyond the entire dialectic of "materiality" and "spirituality" which would belong to the movement of the negative. Such a dead eye has nothing to do with nihilation or annihilation or the void or with the sweeping fire of temporalization. It does not have full "presence," since one cannot fully bring oneself to look at it, yet it is not absent either or even passing into absence. Rather, it is a dead thing on the face of a living being, a thing which shows that at bottom everything is dead and decaying, all bodies are things with eroded surfaces, stained sides, scratched handles, broken grips, torn fabric, scabbed cuts, infected growths, etc.

In such a light, the actions of Poe's character, while extreme, are all-too-normal, all-toohuman. They are the hyperbolic extension of the desire to turn away from the morbid being of things.

\section{III.}

Heidegger: "The full existential and ontological concept of death can now be defined as follows: As the end of Da-sein, death is the ownmost nonrelational and, as such, indefinite and not to be bypassed possibility of Da-sein. As the end of Da-sein, death is the being of this beingtowards-its-end" (BT 239). According to such a concept, even though the dead body has a relatively special status among things (since it is not merely "objectively present" like a material thing but rather is a thing in which we encounter something unliving, something which has lost its life) death properly understood cannot be accessed through any relation to the bodies left 
behind, or to the dying of others; nor can it be accessed through the absence and memories associated with the passage of loved ones (BT 221). For Heidegger, death can never be a being, never one thing among others, not a "process" or a "property" or a "state." Death can only be the coming-nihilation of temporal thrownness which is in each case mine, which is to say that the only death I truly encounter is my own death, my own possibility of impossibility. And even then, proximally and for the most part, I do not encounter this deathliness but rather flee from it through talking about it as a "phenomenon" and attempting to tranquilize myself regarding its very occurrence.

Along these lines, perhaps an "existentiale-reading" would require an analysis of the situation of the story as follows: attempting to deny the perpetual coming-of-death which is essential to his being, lacking the courage to own up to his essential Angst, the madman seeks to remove all traces which remind him of dying and throw him back to the necessity of a possible decision to authentically accept being-towards-death as his own. Thus, the murderer, in attempting to take care of himself through flight into the world, kills the other in an act of radical inauthenticity. In effect, on this reading, the murderer would be the ultimate metaphysician of presence, since in his absolute denial of the temporality of being he would permanently remove the other from sight in order to assure himself of his eternal present.

But such a reading would fail to account for the details of Poe's story. The meticulousness of the murderer's reason, from the beginning, had indeed always been directed toward covering the evidence of the being of death. Poe's narrator:

If still you think me mad, you will think so no longer when I describe the wise precautions I took for the concealment of the body. The night waned, and I worked hastily, but in silence. I took up three planks from the flooring of the chamber, and deposited all between the scantlings. I then replaced the boards so cleverly, so cunningly, that no human eye-not even his-could have detected anything wrong. There was 
nothing to wash out - no stain of any kind - no blood-spot whatever. I had been too wary for that. (298)

But contrary to Heidegger, from the vantage of Poe's fictional ontology, death is something so ontic that covering the dead thing seems to conceal death itself. At least from the madness of the murderer's perspective, not only is the body disposed of so the crime will not be discovered, but also and more primordially, the death of the eye, the deterioration associated with a pulse bound to fail, the wrinkles of age, have also been turned into an opaque surface- - a smooth polished floor. Just after his deed, the murderer congratulates himself that the victim is "stone, stone dead." The horrible, deathly eye has been moved into absolute hiddenness, twice dead and once buried. Imagine his surprise when, while being interrogated by the officers who have been summoned on account of a shriek in the night (an alarming emission from the dying body, like a flow of blood or pus), he begins to hear the heart of the old man beating underneath the floorboards. He detects "a low dull, quick sound-much such a sound as a watch makes when enveloped in cotton" (italics Poe's; 300). The "hideous heart" of the old man as a living dead mechanism continues to beat from beyond the grave. There have been no end of analyses of the recurrence of the sound of the heart as the intrusion of subconscious guilt on the part of the narrator, and in a way, these analyses are accurate. But the madman's guilt is deeper than that of mortification. The madman has attempted to deny the death of things, the "hideousness" of the organ of the heart as it beats with cholesterol-plaqued arteries and half-ruptured chambers, awaiting its inevitable breakdown. But the madman is called back to reality, out of his denial, by the reappearance of death as a thing in the room in which he sits, in and as the bodies of the surrounding men. The police officers are sitting "to rest from their fatigues" and "chatting about familiar things." One can only imagine that one of the officers walks with a limp, the other has a 
rather unsightly scar on his nose, while the third one is balding, age spots already showing on his glistening scalp. Such "signs of impending death" show the narrator that he has been untruthful with himself, that he has in no way removed the dreadful eye and the hideous heart and the wrinkles of age and the deformities of disease from his presence. Death is always already at hand in the very event of social togetherness, or even if one is alone with oneself and one's darkest thoughts, electrical surges passing through singularly serotonin-inflected neural-pathways.

For Heidegger, Da-sein is also summoned out of its anxious fleeing in the face of death and back to itself through the guilty call of its care. Like the narrator, Da-sein has attempted to deny death and is now solicited to confess this denial and make amends, avowing the fundamental truth of human being. But this "wanting to have a conscience" for Heidegger is nothing other than the owning up to the nullity which is at the heart of Da-sein's caring being-inthe-world, which is the same as admitting that Da-sein has no heart. The essence of Da-sein does not essentially involve the heart of the body but rather the ownmost nihilation at the ground of the disclosure of all organic being. When the "police" of its guilt arrive, Da-sein is forced to exclaim not "I admit the deed! — tear up the planks! — here, here! — it is the beating of his hideous heart!" but rather that "I have not projected myself on the null-basis of my be-ing, thus I am not an 'I' but rather everyone and no one, fallen prey to the ontical distortions of my ontological condition! Let me shatter 'myself' and stand free and ready to inherit the history which I will become when I authentically own up to and project from the vastation at the 'heart' of my being!" Although when posed as an actual confession, such an announcement is comical, for Heidegger such a confession is not supposed to be voiced in public but is rather to be heard as the silent voice of Da-sein's thrown singularity. The uncanniness of my guilty condition disquiets me, disrupts me, deconstructs me, and when I testify that I have flown both from the void(ing) of 
be-ing, and into absorption with the ontical things of the world, I privately bear witness to my flight and manifest the courage to bear death as death, which is always already my own.

But to the contrary, for Poe's mad narrator, death is never my own. This is not so because I am not around when I die, so there is no "owning" of death possible at all, but rather because insofar as death always already involves dead and dying things-alien irruptions, protrusions, contusions, members and dismemberments - death calls me into a horrible awareness of "the outside of everything." Not only is there no spirituality, no God, no soul, no transcendent reason, no "subject" that can lie bleeding on the floor, but also there is not even a "free space" left behind in the absence of such divine things, no differencing opening of freedom, no "rip" in being, no "work of the negative," not even the nihilation of time. There is only one bloody thing after another - another ingrown fingernail, another shake of a Parkinsonian hand, another sign of blood in a bowel movement, along with the cracked handle of the hammer, and the traces of DNA left on the killing instrument. What the dead eye "represented" for the narrator was nothing other than that there "is" no site of representation, not even an opening of disclosure, at least not insofar as such sites or openings involve "another mode of being" or even the excess of such a mode. The living dead narrator "discovered" (in the process of losing all in-sight, going insane) that he was always already a dead and dying thing, even "discovering" that his "own" revelation would be classified as madness, merely the aberrant firing of certain neurons, a few biochemicals carrying him on his bad trip. And yet, he maintains: "The disease had sharpened my senses, not destroyed, not dulled them. Above all was the sense of hearing acute. I heard all things in the heaven and in the earth. I heard many things in hell" (Poe 295). Such radical sensation would include hearing that the very senses themselves were things, even the heaven and hell of passion consisting only of earthly, ontic populations. 
Heidegger broaches and yet withdraws the possibility of such a mad reality in his lectures on Aristotle's Metaphysics:

Is this one being (Sein) something before all unfolding, that is, something that exists for itself, whose independence is the true essence of being? Or is being in its essence never not unfolded so that the manifold and its foldings constitute precisely the peculiar oneness of that which is intrinsically gathered up? Is being imparted to the individual modes in such a way that by this imparting it in fact parts itself out, although in this parting out it is not partitioned in such a way that, as divided, it falls apart and loses its authentic essence, its unity? Might the unity of being lie precisely in this imparting, parting out? And if so, how would and could something like this happen? What holds sway in this event? (Heidegger, Metaphysics 25)

If being is totally "parted out," given as a plurality of things totally exhausted in their multiplicity, "granted" as an exteriority without end, then there would be no "space" or "place" or "site" or "region" or even "opening" or "coming forth." There would only "be" a mad manifold of beings without unity or sense. In confronting this mad manifold, assuming that one expected some beyond, some transcendence, some impetus otherwise (dis-locating the immanence of the present, allowing it to be labeled as "immanence of the present"), then the appropriate response to the mad awareness that "there is neither an outside nor an inside," that "this" is every thing - these bloody hands, this beating heart — would be one of horror, not anxiety. Anxiety would happen with the confrontation of the "no-thing-ness" of be-ing as it emptily mimes the creative transcendence of God, as one finds an endlessly creative falling abyss as the basis of who one is, turning from this falling abyss incessantly (as one would anxiously flee from a cliff). But in a mad confrontation with "the immanence of the present" there would be nowhere to turn, except where one always already was, together with the brutal plurality of things. Heidegger goes out of his way in the paragraph above to re-introduce the siting of transcendence in the heart of beings, effectively turning from them as he turns towards them. As his thought moves from "foldings" and "modes" toward "the unity of being" as the 
parting/opening of the manifold, he asks the quite metaphysical question "how would and could something like this happen?" In a sense, Poe's mad narrator is far beyond Heidegger at this point, since he knows better than to ask such a question. He finds himself confronted with the mad death of things, plurality without the eternal transcendence of life, and he recoils in what might be called "authentic horror" at this death. While it is true he is mad and cannot bear his own insight (so he attempts to destroy the death of things with his blade), he possesses too much wisdom to ask such questions as "what is the essence of deterioration?", "how does aging come to pass?", or "in what sense does history give us lives whose sense passes away along with it?" The narrator knows that there is no answer to these questions, that they are thus not even questions, that one cannot mitigate the horror of the death of a thing by thinking it through.

\section{IV.}

Not even here. The present essay, of course, is not a work of fiction. At best, it is an attempt at thinking which is poised on the brink of failure, situated between the loss of things through conceptual annihilation and their promised return, inheriting their eidola through irruptions of Poe's prose. This essay speaks of the depths of singularity or mad specificity or endlessly concrete detail, and it attempts to stay with the essence of shallowness in the confrontation of dead and disfigured and stained and decomposing things which meet the gaze, touch the skin, and whose odors intrude into the nose and whose shrieks carry one toward a body dying once and alone with a universe of imperfections constituting its morbid beauty. Insofar as it speaks from the depths this essay speaks poetically and risks incorporating fictional words into its poetic movement. Heidegger: "The opposite to the purely spoken, to the poem, is not prose. Pure prose is not 'prosaic.' It is as poetic and thereby as rare as poetry" (Poetry 208). 
But when the "prose" of thinking is thus purified, inflected towards the poetic, resonating with it in a strange disclosive sameness, there are advantages and disadvantages, gains and losses, insofar as such thought attempts to bear witness to the truths of madness and death in their instantiations in the bodies of the earth. In his later thoughtful writing on poetry, language, madness, and death, Heidegger only attends to the advantages and gains, to the extent that the pure rarity of his thinking is formed entirely by this one-sided attentiveness, an attentiveness which conceals as much as it reveals.

For an essential instance, in precisely the place where he does address the madman and his relation to death, in "Language and the Poem," later Heidegger follows his characteristic pattern of turning away from dead and dying things and towards the pure (dis)essence(ing) (Wesung) of their presentation. In his reading of a single line from Trakl's "Psalm" everything about later Heidegger's continuing fundamental relationship to death is exposed. Trakl writes: "Der Wahnsinnige ist gestorben" ("The madman is dead") (Heidegger, Language 173). Amazingly, about this dead madman, Heidegger makes a series of remarkable interpretive claims: 1. The madman is not really dead. "The dead one lives in his grave. He lives in his chamber so quietly and pensively that he plays with his snakes. They cannot harm him." 2 . The dead madman is not really a mentally-ill person (Geisteskranken). "Madness (Wahnsinn) does not mean the sense that hallucinates the nonsensical. The madman senses, and he even senses as none has before. But he remains mad, without the sense of the others. He is of another sense." Heidegger draws the mad, separated one, the stranger who is departed, displaced in relation both to the boy Elis from Trakl's "To the Boy Elis" ("Oh how long, Elis, have you been dead") and to Nietzsche's Zarathustra, the one who projects beyond Platonism. But about Elis (and by implication the stranger, the madman, and even Zarathustra) Heidegger asserts: "Elis is not a 
dead one who deteriorates (verwest) into the lateness of dying life. Elis is rather the dead one who purifyingly moves (entwest - one would want to say decontaminates) into earliness" (Language 175). And directly following, with another astounding, macabre linking, Heidegger connects the dead, mad, stranger, by way of Elis (become Zarathustra's child) to the unborn. Heidegger recalls Trakl's line from "Bright Spring": "The unborn tends its ownmost calm.” This unborn "protects and preserves the quiet childhood in the coming awakening of the human race." "Thus," Heidegger concludes, "the one who died early lives calmly." This stranger become madman become living corpse become (sexless) child become unborn lives quietly for the sake of the future, a perpetually posthumous being, perhaps even a philosopher of the future, one of the wicked Nietzsche saw coming.

Such conclusions seem incontrovertible at the distance from which Heidegger reads, a distance which allows for the purifying poetization of poetry itself, a distillation of its forms into essential words. But if one looks at Trakl's words a bit more closely, with a more "prosaic" mind, one might notice equally astonishing occlusions in Heidegger's reading. To unearth these strange fossils, we only need to attend to the conclusion of Trakl's "Psalm" where the dead madman is first invoked:

It is an empty boat which pushes down the black canal in evening.

In the gloom of the old asylum, human ruins deteriorate.

Dead orphans lie at the garden wall.

From gray rooms proceed angels with shit-flecked wings.

Worms drop from their yellowed lids.

The square before the church is dark and silent, as in the days of childhood.

Earlier lives glide by on silver soles.

And the shadows of the damned descend to sighing waters.

In his grave, the white magician plays with his snakes.

Silently above the place of skulls open God's golden eyes. (Trakl 16-17) 
One can easily see the amount of elision involved in Heidegger's dissociation of death and madness from bodily deterioration in Trakl's poetry. Taking into account this one intervening stanza separating the madman from the magician in the grave, the magician who supposedly still lives (while noting the two other equally problematic stanzas with their mentions of bloody contagia, bats, blindness, poverty), one may come to an opposite determination regarding the "significance" of the death of the madman: the madman does not live. Rather, he has magically transformed from a vibrant presence into a rotting corpse, "playing" with the snaking worms which eat his remnants. The ruins of the madman's mind deteriorated in the old asylum, drawing him down from heavenly transcendence into a perverse relation with dead bodies (perhaps orphans he murdered) and excrement, damned through a bio-fixation allowing no elevation from the sighing waters of the singular earth. The only future, the only "one to come," the only "unborn child" of the body is the skull which rests on Golgotha, the skull which draws God's golden eyes and simultaneously shows this God that He has been as mad and dead all along as the madman to whom He can offer no salvation. The mystical divine vision of death is here drawn into a revelation of its impotence in the face of the contingent horror of no future at all.

One might imagine Poe's madman from The Tell-Tale Heart carrying out such a perverse reading from the enlightened vantage of his asylum cell, perhaps encouraged by his anachronistic knowledge of Trakl's all-too-earthly (and psychopathological) death from depression and cocaine. Perhaps awaiting execution in the cell next to him, Poe's equally mad narrator from The Black Cat whispers through the walls, whispers of a "spirit of perverseness" he senses in Trakl's writing, the same spirit which led this narrator not only to do what he knew he should not (gouge his beloved cat's eye out, hang it from a tree, murder his wife with an ax) but also perpetually to 
obsess about every morbid detail of his actions. Like the Heart's narrator, the Cat's narrator attempted to cover up his crime assiduously through disposing of the body:

At one period I thought of cutting the corpse into minute fragments, and destroying them by fire. At another, I resolved to dig a grave for it in the floor of the cellar. Again, I deliberated about casting it in the well in the yard-about packing it in a box, as if merchandize, with the usual arrangements, and so getting a porter to take it from the house. Finally I hit upon what I considered a far better expedient than either of these. I determined to wall it up in the cellar - as the monks of the middle ages are recorded to have walled up their victims. (Poe 261)

And also like the Heart's narrator, the Cat's narrator was undone by the re-intrusion of the corpse out of its hiddenness, in this case revealed by a cat which reminded him of the one he had killed, a cat whose cries brought the investigators to tear down the wall behind which his wife's body was immured:

The corpse, already greatly decayed and clotted with gore, stood erect before the eyes of the spectators. Upon its head, with red extended mouth and solitary eye of fire, sat the hideous beast whose craft had seduced me into murder, and whose informing voice had consigned me to the hangman. I had walled the monster up within the tomb! (Poe 263)

From such a vantage, a vantage of the specifics of fiction in resonance with the mortal detail of death and madness, one may well have disturbing suspicions about what lies hidden behind the elisions in Heidegger's poetic readings. Not only: what is essentially concealed in the opening disclosure of speaking? But also: What is Heidegger concealing in his re-inscription of death and madness as projective promise? What torturous impulses, what violent images, what secret hatreds, what waves of nausea, what childhood horrors, what sexual fantasies, what racial antipathies, what impulses to power, what real abuses lie behind the walls of the enactment of the "homecoming of the human race into the quiet beginning of its stiller swaying?" (Heidegger, Language 191). 
Doubtlessly, such questions have no answers, and furthermore, they remain at the level of psychological interrogations. And yet, such questions, questions brought forth precisely by a curiosity toward the details of mere being, do not merely call for the florid, journalistic description of the life of the thinker. Rather, they draw poetic thinking to the site of its necessary exclusions. In order for thinking to take place, there must be a withdrawal from (or even willful repression of) fixation on morbid impulses, perverse tendencies, violent fulminations (even here, in the midst of all these horrible references). Words are not wounds. There is indeed a calm anticipation which constitutes the life of the mind. This calm anticipatory movement of disclosure which has here been termed "the poetic" is not to be found in the objective presence of the poem (even though the elegance of poetic economy and cadence draw it forth) but rather is the space in which the poem is received. Likewise, the morbid perversity, the obsessiveness, the fixation on graphic detail of "the fictional" is not to be found in the objective presence of the short story or the novel (even though their intricate wanderings and imbricated constellations draw it forth) but rather is the space in which fiction is received. Certainly, in many places, the poetic distillations of Heidegger in regard to Trakl's work seem appropriate. But, as is demonstrated here, there is another space in which even the poem can be inherited.

If Heidegger's thinking disavows such a space, if "Heidegger's thinking" is nothing other than a name for the future of thinking itself as "the poetic," then this does not prove that such a space is of no relevance for an "authentic" relation to being. Rather, it would only indicate that "thinking" would be a name for a certain occurrence of purification, symbolization, essentialization, and gathering which allows be-ing to manifest within a dimension of projective hope. Through the lens of the other, half-blind fictive eye, "being" would "appear" quite differently; not as that which calls for thinking but rather as that which cannot be thought at all, 
that which can only be lingered with, endured, fugitively described, and acknowledged in its horror, even that which must be so acknowledged lest it return with the perverse force of deadly, exclusive violence.

One might even say (reversing Heidegger's announcement cited earlier) that the opposite to the impurely spoken, to fiction, is not poetry. Impure poetry is not "poetic." It is as fictional and thereby as common as fiction. Perhaps Heidegger's great foe Adorno should have written not that "There is no poetry after Auschwitz" but rather that there has never been any "pure poetry," before or after Auschwitz, that poetry is not the fantasy of a distilling projection which would entomb suffering, fragile, and deteriorating bodies (and the minds contained in psychopathological brains) in silent crypts. The "thoughtful essay" (which resonates in poetic sameness with the poem) would have to poise itself at the edge of deteriorating into unthought images of dead and dying bodies in order to begin to bear witness to this silence: thus out of the opening propagated by the thinking of Heidegger, we would have to commence to tell stories.

\section{V.}

This essay ends with the deaths of two women, recounted in two fictional presentations. But before I narrate these deaths, number them specifically, tell the tales of each woman's demise, singularly and without precedent, allow me to return to the opening theme of the essay for a brief re-emphasis, even though it has been continually in the background of my discussion. Philosophy can barely tolerate, if at all, literary specificity, the specificity of "Dichtung als Belletristik." Philosophy has told itself that it deals with the concept or what comes after the concept in zones of quasi-transcendentality. It has told itself that it is of the essence of language to lose the things themselves, perpetually, to have them vanish in traces of imagined forms, 
metaphysical representations, historical ideas, scientific descriptions, and even traces "themselves," doubled writing which torsions beyond the name of being in the inscription of différance. And yet, when one attempts to acknowledge the death of things, the decaying and imperfect and deteriorating things of the world, things such as Socrates mentions in the Parmenides only to disavow_-"hair, mud, filth, and other things which are base and vile"-and especially when one attempts to acknowledge the human body and the human mind as the locus of such things, then one is forced to enter into a language resistant to the generality of conceptualization and even resistant to the sublimation of singular figures into engravings of excess (Plato 6).

For instance, in the above paragraphs, each time I evoke the death of things beyond the determining disclosure of Heidegger's ontology, with appeals to the prose of Poe or autobiographical eruptions or even vague references which have for me all-too-concrete connotations (the horror towards the death of things is always operative in writing), I find myself moved into an idiom of specificity where the words magically fixate on singular beings. Of course, all words, in being repeated and repeatable, in being cast forth, in being words at all, are always already generalities, transported outside the evidence of the immanent present. And yet, as the death of things is broached, as you are shocked into the eerie proximity of flea eggs on the neck of your cat, of the weird twitch of your bird's head, of the scar from the grill-burn which will always be there, of the pain in the throat from esophageal reflux, among other things, then you find these general words to be pulled to these specific points through the weird gravity of the morbid detail of singular life. Much about this life can be disclosed by paraphrasing it as beingin-the-world, which shares quite general, ontological structures with the lives of others, and much can be learned about the "whole" of the life of (to use a phrase Heidegger would have 
found abhorrent) "Da-sein as a species" (where fundamental ontology could be redescribed as a sort of weird existential biology). However, there are things about life, occurrences of beings, a radically nominalized ontology which can only be avowed (at least within language) through the shocks, winces, raptures, and shrieks of fictive prose, even when this prose comes forth in the apparently non-fantastic realms of autobiography or commentary on the real.

\section{$1^{\text {st }}$ woman}

[T] hen without those doors there did stand the lofty and enshrouded figure of the lady Madeline of Usher. There was blood upon her white robes, and the evidence of some bitter struggle upon every portion of her emaciated frame. For a moment she remained trembling and reeling to and fro upon the threshold - then, with a low moaning cry, fell heavily inward upon the person of her brother, and in her violent and now final deathagonies, bore him to the floor a corpse, and a victim to the terrors he had anticipated. (Poe 219)

There is a thematics of what has been called here the desire for the death of the dead which runs throughout Poe's work, not merely residing beneath the floorboards of The Tell-Tale Heart and behind the walls of The Black Cat. Along with this thematics, there is also a countermovement of the return of such death from its attempted destruction or covering, a countermovement of ghastly resurrection. Lady Madeleine embodies this counter-movement in the eeriest and most provocative fashion possible, though she scarcely appears in The Fall of the House of Usher, much as the old man scarcely appears in The Tell-Tale Heart, or the wife scarcely appears in The Black Cat (as if there were a literary mimesis of this desire flowing through Poe's activity of composition, as if he almost could not bear the figure of the dead any more than his characters could).

Suffering from a severe inexplicable state where she is dissolving into a condition of perpetual catatonia, Lady Madeleine apparently dies. It is almost as if she is, for Poe, a prophetic 
"natural occurrence" of the entry of the body into the indistinct zone of what Agamben calls bare life — in the story she exists neither as a biological being nor as a social presence, but only as the living-dead, pure catalepsy, glimpsed merely as a ghostlike movement, a(n) (apparently) dead body, and in her horrible returning visitation. In the story this woman has been reduced by her illness (and perhaps by her brother) to a grave-like silence.

She (apparently) dies out of the sight of the narrator. He and Roderick Usher take her body and entomb it in the family crypt, (for mysterious reasons) preserving it for a later burial. (One familiar with Poe would also here recall the macabre entombment which takes place in The Cask of Amontillado, another site of the death of death in his work.) As they entomb her, they are confronted with her strange hovering between death and life:

Our glances, however, rested not long upon the dead-for we could not regard her unawed. The disease which had thus entombed the lady in the maturity of youth, had left, as usual in all maladies of a strictly cataleptical character, the mockery of a faint blush upon the bosom and the face, and that suspiciously lingering smile upon the lip which is so terrible in death. (Poe 213)

The men, awed by the sight of living-death, retreat after replacing and screwing down a lid upon it and sealing it behind an iron door. And yet, in the horrific conclusion, the body returns, returns to die, already dead in a way, the dead returning to kill the living who have attempted to seal her out of sight. But as anyone familiar with the story knows, she had already been returning, attempting to be heard out of the silence of her entombment. With his unnaturally heightened senses, Roderick Usher heard her scratching and moaning in the crypt for days. He "dared not," however, remedy their error, if it was an error, if he had not somehow known she was alive all along, if he had not already been responsible for her catatonia, perhaps having transformed her into the living-dead long ago through unspeakable acts of abuse. While she scratched at the walls of her tomb he discussed literature together with his friend, first reciting a 
poem of his own composition-“The Haunted Palace." While the entombed one deteriorated, Roderick poetized, and then they listened to the narrator read a tale of knightly conquests. As the narrator reads the story, a story whose "uncouth and unimaginative prolixity" he suspects will cause it to be of little interest to the refined sensibilities of Roderick, the sounds of Madeleine's escape echo through the house as horrific counterpoint. While the narrator reads of the breaking of a door he notices the same cracking and ripping sound reverberate through the mansion as Madeleine tears off the wooden lid with her bare hands. While the narrator reads of the death shriek of a slain dragon he hears "an unusual screaming or grating sound" vibrate through the walls as Madeleine cries out from the madness of her condition. While the narrator reads of the falling of a great shield to the floor a "distinct, hollow, metallic, and clangorous, yet apparently muffled reverberation" rings within the great house as Madeleine opens the great iron door behind which she was left for dead.

Such horrific sounds, unintentionally responding to the space of literature as it describes and presents in its flowing cadences, would be nothing other than the sounds of the death of things as they arise and return us to a horrible authenticity, exposing the intellectualized "courage for death" as a shallow heroism of the spirit, the precursor to any fascism.

$$
2^{\text {nd }} \text { woman }
$$

From the dark opening of the worn insides of the shoes the toilsome tread of the worker stares forth. In the stiffly rugged heaviness of the shoes there is the accumulated tenacity of her slow trudge through the far-spreading and ever-uniform furrows of the field swept by a raw wind. On the leather lie the dampness and richness of the soil. Under the soles slides the loneliness of the field-path as evening falls. In the shoes vibrates the silent call of the earth, its quiet gift of the ripening grain and its unexplained self-refusal in the fallow desolation of the wintry field. This equipment is pervaded by uncomplaining anxiety as to the certainty of bread, the wordless joy of having once more withstood want, the trembling before the impending childbed and shivering at the surrounding menace of death. This equipment belongs to the earth, and it is protected in the world of 
the peasant woman. From out of this protected belonging the equipment itself rises to its resting-within-itself. (Heidegger, "Origin" 159)

The peasant woman, of course, had no idea it would be her shoes which would be immortalized as an example to show the way in which the work of art sets truth to work, allowing the things of the world to be disclosed against the background of the withdrawn recessing of earthliness, preserving through founding an awesome beginning. She had no idea that it would be her shoes which would be drawn from the painting and into communication with the erecting of the Greek temple, allowing passages between worlds, transitions between beginnings, as the opening of presence leaps into dark smudges of paint, allowing the cracks in classical architecture to be seen as inherent to its being. She had no idea that it would be her shoes which both first shine forth as equipment while at the same time, in their being twisted beyond use on the painted surface, disclose the essence of equipmentality, the essence of the striving engagement allotted to mortals on the earth.

If she had known this, before she sold them to the small shop in the village owned by her uncle, who would later load them onto a train car where they would embark on an unremarkable journey which would eventually take them to the floor beneath Van Gogh's canvas, she would have perhaps (along with insisting on more of a profit for her sale) affixed a short note which afforded clearer understanding of their history. On the one hand, Heidegger was right, these were shoes which carried within them, in the dark recesses of their other interior, seasons and toil, worry and hope, birth and death. The nexus of the world radiated from the simple being of the things that the shoes persisted as. But on the other hand, she had sold the shoes and they were taken away, removed and detached from their being, and her life as a peasant, as a farmer, as one 
who lived in the midst of the richness and poverty of the granting of the earth had long ago passed.

Perhaps her note would include the following details explaining the reason for this initial detachment. She sold the shoes because she could not stand to have them in the house. She could not stand to have them in the house because she had been wearing these shoes when lightning struck the field where she was working alongside her husband, Roland. The bolt-from-thedarkening-clouds, the clouds they braved because of needing to secure enough food for the harsh winter, flashed to her right, surprising and blinding her. She was thrown to the ground in confusion and did not immediately comprehend what had happened. When she righted herself, she found her husband Roland lying on the crumbled earth clutching his chest, gasping, his clothes smoldering, the scent of his burned flesh in her nose. The rain had begun pouring and the wind roaring and the lightning sparked wildly in the heavens. She knew she had to get him back to the house. In a mad instant of decision, she ran to get her daughters to help transport him home by dragging his body on a burlap sack. But as she ran, her shoes caught in the roots and plants erupting in every row, tearing the leather, further soiling the work-worn surface.

So she took off the shoes and flung them to the ground and ran with bare feet. Weeks later, Roland was dead and in the dirt—he never awakened, but twitched for hours before he died, his body still conducting the electricity which eventually killed it. However, before she sold the farm and moved in with her daughter's family, since it was all she could do, she wandered to the circle of dead plants where the terrible thing had happened, almost expecting to find him still lying there, twitching, but she found her shoes instead, half buried in mud and filled with rainwater. She shuddered as she held them in her hands and knew she would never wear them again, nor allow them to become keepsakes of tragedy. Thus, they went to her uncle's store, 
along with the farming tools and Roland's clothes and most of the other vestiges of her peasant existence. She died seven months later after crying nearly every night for her lost husband.

Would such a note destroy the poetry of Van Gogh's art, and the poetry of Heidegger's reading of that art? Would such a detailed account draw the shoes from Heidegger's elegant yet completely banal and general account of the truth of equipmentality and the being of things into the irrelevance of journalism? Heidegger had to imagine the site of the shoes, the placement of the shoes, the life of the wearer, but by what standard did he license himself to stop imagining, to divide essence from singular accident? And according to what principle did he allow himself to turn "the peasant woman" into an icon, an exemplar, a model of Da-sein, purified from the terrible contingent eccentricities of life? Or even, what could Heidegger not bear about the damaged contingency of her life, about the real togetherness with the trauma and mutilation of the body of the other, which would cause him to turn away from her at the instant of the composition of his essay, as he stopped imagining and even stopped thinking?

Such unanswerable questions would lie on the stone and root-filled other way toward the essence of truth, the shadowed path which runs through the valley of dead things.

\section{Works Cited}

Derrida, Jacques. Aporias. Trans. Thomas Dutoit. Stanford: Stanford University Press, 1993.

- Speech and Phenomena and Other Essays on Husserl's Theory of Signs [translation of Voix to "Voice" from "Speech" mine]. Trans. David B. Allison. Evanston: Northwestern University Press, 1973.

—. "Restitutions." Trans Geoff Bennington and Ian McCloud. The Truth in Painting. Chicago: University of Chicago Press, 1987. 255-382.

Heidegger, Martin. Aristotle's Metaphysics 01-3: On the Essence and Actuality of Force. Trans. Walter Brogan and Peter Warnek. Bloomington: Indiana University Press, 1995. 
Being and Time. Trans. Joan Stambaugh. Albany: SUNY Press, 1996.

- On the Way to Language. Trans. Peter D. Hertz. New York: Harper and Row, 1971. Emended translations.

—. Unterwegs Zur Sprache. Gesamtausgabe 12. Frankfurt Am Main: Vittorio Klostermann $\mathrm{GmbH}, 1985.31-78$.

—. Poetry Language Thought. Trans. Albert Hofstadter. New York: Harper and Row, 1971.

—. "The Origin of the Work of Art." Trans. Albert Hofstadter. Basic Writings. San Francisco: Harper Collins, 1993. 143-212.

Plato. The Parmenides. Trans. Benjamin Jowett. Maryland: Arc Manor, 2008.

Poe, Edgar Allan. Tales of Mystery and Imagination. New York: Henry Frowde Press, 1903.

Trakl, Georg. Poems and Prose: A Bilingual Edition. Trans. Alexander Stillmark. Evanston: Northwestern University Press, 2005. Emended translations. 